\title{
Snow as a driving factor of rock surface temperatures in steep rough rock walls
}

\author{
Anna Haberkorn ${ }^{\mathrm{a}, \mathrm{b}, *}$, Martin Hoelzle ${ }^{\mathrm{b}}$, Marcia Phillips ${ }^{\mathrm{a}}$, Robert Kenner ${ }^{\mathrm{a}}$ \\ a WSL Institute for Snow and Avalanche Research SLF, Flüelastrasse 11, CH-7260 Davos, Switzerland \\ b Unit of Geography, Department of Geosciences , University of Fribourg, Chemin du Musée 4, CH-1700 Fribourg, Switzerland
}

\begin{abstract}
Observations show that considerable amounts of snow can accumulate in steep, rough rock walls. The heterogeneously distributed snow cover significantly affects the surface energy balance and hence the thermal regime of the rock walls.

To assess the small-scale variability of snow depth and rock temperatures in steep north and south facing rock walls, a spatially distributed multi-method approach is applied at Gemsstock, Switzerland, combining 35 continuous near-surface rock temperature measurements, high resolution snow depth observations using terrestrial laser scanning, as well as in-situ snow pit investigations.

The thermal regime of the rock surface is highly dependent on short- and longwave radiation, albedo, surface roughness, snow depth and on snow distribution in time and space. Around $2 \mathrm{~m}$ of snow can accumulate on slopes with angles up to $75^{\circ}$, due to micro-topographic structures like ledges. Hence, contrasts in mean annual rock surface temperature between the north and the south facing slopes are less than $4{ }^{\circ} \mathrm{C}$. However, significant small-scale variability of up to $10^{\circ} \mathrm{C}$ in mean daily rock surface temperature occurs within a few metres over the rock walls due to the variable snow distribution, revealing the heterogeneity and complexity of the thermal regime at a very local scale. In addition, multiple linear regression could explain up to $77 \%$ of near-surface rock temperature variability, which underlines the importance of radiation and snow depth and thus also of the topography.

In the rock faces the thermal insulation of the ground starts with snow depths exceeding $0.2 \mathrm{~m}$. This is due to the high thermal resistance of a less densely packed snow cover, especially in the north facing slope. Additionally, aspect induced differences of snow cover characteristics and consequently thermal conductivities are observed in the rock walls.
\end{abstract}

\section{Introduction}

Pronounced rock fall activity has been observed in Alpine permafrost regions over the last decades (Deline et al., 2012; Gruber and Haeberli, 2007; Gruber et al., 2004a; Ravanel and Deline, 2010). Rock slopes containing ice are sensitive to ongoing climate change (IPCC, 2013). Rising air and rock temperatures can reduce the effective thermal stress in ice filled rock joints (Haeberli et al., 1997), enhancing destabilization and

Abbreviations: AWS, automatic weather station; $\mathrm{BH}$, borehole; DTM, digital terrain model; HS, snow depth; MAAT, mean annual air temperature; MAGST, mean annual ground surface temperature; N, north-west slope; NSRT, near-surface rock temperature; $\mathrm{p}$, level of significance; PISR, potential incoming solar radiation; $\mathrm{R}$, ridge; $\mathrm{R}^{2}$, coefficient of determination; S, south-east slope; SO, surface offset; STD, standard deviation; TA, air temperature; TLS, terrestrial laser scanning.

* Corresponding author at: WSL Institute for Snow and Avalanche Research SLF, Flüelastrasse 11, CH-7260 Davos, Switzerland. Tel.: +41 814170 213; fax: +4 41814170 110.

E-mail addresses: haberkorn@slf.ch, anna-haberkorn@gmx.de (A. Haberkorn), martin.hoelzle@unifr.ch (M. Hoelzle), phillips@slf.ch (M. Phillips), kenner@slf.ch (R. Kenner). possibly leading to rock slope failure (Krautblatter et al., 2013). Rock temperature data are therefore essential for a detailed understanding of thermo-mechanical processes in rock walls, and to model and predict permafrost related hazards (Krautblatter et al., 2011), which may threaten human lives and infrastructure in the densely populated Alps.

Snow has a thermal influence on the ground due to its low thermal conductivity (Fierz and Lehning, 2001), high surface albedo and the consumption of energy during snow melt (Sturm et al., 1997; Zhang, 2005). The snow cover either has a warming or cooling effect on ground temperatures, depending mainly on the snow depth (Luetschg et al., 2008; Phillips and Schweizer, 2007), as well as on its initial timing and duration (Hoelzle et al., 2003; Zhang et al., 2001). A thick snow cover $(>0.6 \mathrm{~m}$ ) decouples the rock surface from the air temperature due to increasing thermal insulation with increasing snow depth (Keller and Gubler, 1993), resulting in an increased MAGST (Keller and Gubler, 1993; Luetschg et al., 2003; Matsuoka and Sakai, 1999; Zhang et al., $2001)$. In contrast, a thin $(<0.15 \mathrm{~m})$ and patchy snow cover leads to ground cooling due to an increase in longwave emissivity and albedo at the surface, in combination with a low thermal resistance of the 
thin snow cover (Keller and Gubler, 1993; Luetschg et al., 2008). Snow depth and its distribution therefore influence the existence of permafrost in both gently inclined slopes and in steep rock faces. The occurrence of snow in steep rock walls has been confirmed by Wirz et al. (2011), a possible influence of snow on spatially distributed rock surface temperatures is discussed by Magnin et al. (2015), as well as Hasler et al. (2011). Haberkorn et al. (2015) provide a first quantitative (measured and modelled) investigation of the effects of snow on rock thermal processes.

To account for the complexity of rock walls and their thermal conditions, spatially distributed rock temperature measurements in various types of rock walls covering different aspects are necessary. Measurements in compact, near-vertical and also snow free rock (Gruber et al., 2003), as well as distributed surface energy balance modelling (Gruber et al., 2004b; Mittaz et al., 2000; Noetzli et al., 2007) to extrapolate rock thermal conditions in space and time underline the dominance of topography on permafrost distribution in steep bedrock. These authors found $7-8{ }^{\circ} \mathrm{C}$ warmer MAGST in Alpine rock faces exposed to solar radiation than in shaded ones. The assumption of a lack of snow in rock walls exceeding $50^{\circ}$ due to gravitational processes such as avalanching and sloughing (Blöschl and Kirnbauer, 1992; Seligman, 1936; Winstral et al., 2002) is not applicable for rough rock walls with a complex micro-structure (Haberkorn et al., 2015). This implies that the thermal regimes observed and modelled in the idealized case of vertical compact rock are different. Hasler et al. (2011) reported a likely reduction of MAGST of $2-3^{\circ} \mathrm{C}$ in moderate to steep $\left(45^{\circ}-70^{\circ}\right)$, fractured rock faces exposed to solar radiation. This is assumed to be due to the accumulation of snow persisting during the months with most intense solar radiation. The thermo-insulating effect of snow accumulating locally in steep rock is also addressed by Magnin et al. (2015). For a thick snow cover $(>0.6-0.8 \mathrm{~m})$ the latter observed a MAGST increase in shaded areas comparable to that in gentle mountain slopes and in contrast, a MAGST decrease in sun-exposed faces due to the higher surface albedo of snow, thus reversing the thermo-insulating effect of thick snow.

The snow cover influences the rock surface energy balance, due to changes in both the radiation budget and the turbulent fluxes of sensible and latent heat at the rock surface (Armstrong and Brun, 2008). Although Hasler et al. (2011) and Magnin et al. (2015) assume reduced MAGST differences between north and south facing rock walls due to the accumulation of snow on micro-reliefs, HS are only estimated in these studies and are described qualitatively in terms of 'thin' or 'thick' snow accumulations rather than quantitatively. High quality snow depth and snow characteristic data in combination with rock temperature measurements are therefore required to better quantify the impact of the snow on the rock thermal regime.

High resolution TLS is suitable to measure snow depths accurately and to determine the spatial distribution of snow, both in gently inclined slopes (Deems et al., 2013; Grünewald et al., 2010; Prokop, 2008) and in steep, rough rock walls (Haberkorn et al., 2015; Wirz et al., 2011). The accumulation of considerable amounts of snow $(2-3 \mathrm{~m})$ in slopes between $70^{\circ}$ to even $90^{\circ}$ due to local microtopographic asperities was observed by Haberkorn et al. (2015). The heterogeneous spatial distribution of the mountain snow cover (e.g. Pomeroy and Gray, 1995; Seligman, 1936) is mainly attributed to the deposition and redistribution of snow due to wind (Lehning et al., 2008; Schweizer et al., 2008; Trujillo et al., 2007; Wirz et al., 2011), to micro-topographic properties such as terrain roughness, terrain concavity and distance to underlying ledges (Haberkorn et al., 2015; Magnin et al., 2015) and to spatially varying ablation processes due to local radiation (Mott et al., 2011) and shading from surrounding terrain.

To assess the impact of the heterogeneously distributed snow cover on the strong small-scale variability of NSRT, steep north and south facing rock walls were investigated over a period of 2 years at Gemsstock, Swiss Alps. The sectors of the rock walls where snow can or cannot accumulate are characterized and the thermal response of the rock is analysed. To do this, we applied a spatially distributed multi-method approach with a high temporal and spatial resolution. This involved combining 35 continuous NSRT measurements, remote observations of the snow depth and its distribution using TLS and in-situ snow cover observations (snow pits) at different stages over two consecutive winters.

The dependence of the surface offset and consequently of NSRT on air temperature, snow depth, terrain roughness and PISR is investigated using multiple linear regression and is discussed in the context of the heterogeneous and complex processes occurring in steep mountain rock walls.

\section{Study site}

The study site is part of the Gemsstock mountain ridge $\left(46^{\circ} 36^{\prime} 7.74^{\prime \prime}\right.$ $\mathrm{N} ; 8^{\circ} 36^{\prime} 41.98^{\prime \prime} \mathrm{E} ; 2961 \mathrm{~m}$ a.s.l.), located above Andermatt, central Swiss Alps (Fig. 1). The rocky flanks of the ridge investigated face north-west and south-east and are subsequently simply referred to as the $\mathrm{N}$ and $\mathrm{S}$ slopes. The $40 \mathrm{~m}$ high slopes are $40^{\circ}$ to $70^{\circ}$ steep, with vertical to overhanging $\left(>90^{\circ}\right)$ sections and extend from an elevation of $2890 \mathrm{~m}$ a.s.l. to $2930 \mathrm{~m}$ a.s.l. The ridge has a width of $40 \mathrm{~m}$ at its base, and tapers off towards the top. The whole $\mathrm{N}$ facing scarp slope and the upper part of the $\mathrm{S}$ facing dip slope consist of bare Gotthard paragneiss and granodiorite, with quartz veins, whereas the lower half of the southern slope is partly covered by patches of grass and moss. On the local rock wall scale micro-topographic contrasts dominate the $\mathrm{N}$ face with a series of practically horizontal ledges intersecting the rock wall, which correspond to joints striking southwards at $70^{\circ}$ and alternating with steep to vertical parts. In contrast, the $S$ facing dip slope is rather smooth and homogeneous (Fig. 2).

Gemsstock is located directly on the main divide of the Western Alps, and is thus affected both by northerly and southerly airflows. Meteorological data are obtained from an on-site AWS located at the northern foot of the rock wall (Fig. 1). Meteorological differences to surrounding AWS at lower elevations (Gütsch, $2287 \mathrm{~m}$ a.s.l., $6 \mathrm{~km}$ north of Gemsstock; Urseren, 2170 m a.s.l., 8 km west of Gemsstock; Bedretto, $2450 \mathrm{~m}$ a.s.l., $11 \mathrm{~km}$ south-west of Gemsstock) are clearly reflected in the enhanced orographic precipitation from the north and the south at Gemsstock. Maximum snow depths are $4.5 \mathrm{~m}$ at the AWS Gemsstock compared with $3.5 \mathrm{~m}$ at the close by AWS Gütsch (Haberkorn et al., 2015). Prevailing wind directions are from north-east to north-west, but also from the south during föhn storms. The MAAT measured at the AWS Gemsstock was $-2.6^{\circ} \mathrm{C}$ during the study period between 1 August 2012 and 31 July 2014 . The year $2012-2013$ was $1{ }^{\circ} \mathrm{C}$ warmer than 2013-2014 (Table 1), although the mean winter temperature (December to February) in $2012-2013$ was $3.6^{\circ} \mathrm{C}$ colder. Nevertheless, both years were warmer $\left(1.0\right.$ to $1.5^{\circ} \mathrm{C}$ ) than the MAAT in the reference period 1981-2010 measured at the MeteoSwiss AWS Gütsch. The snow cover development during the two particularly long and snow rich winters was relatively similar at Gemsstock (Fig. 3), although most snowfalls in the year 2012-2013 were dominated by northerly airflow, in contrast to 2013-2014, when snowfalls were dominated by southerly airflow, as shown by data from neighbouring AWS. However, initial and maximum snow depths were lower in winter 2013-2014 and hence the timing of snow disappearance differed between the two winters.

Borehole temperatures measured continuously since 2005 in a horizontal borehole through the Gemsstock ridge (Figs. 1c, 2) indicate that there is no permafrost here (PERMOS, 2013). However, ice has been observed in rock fall scars at nearby locations on the $\mathrm{N}$ facing slope. Near-surface freeze-thaw cycles take place in autumn and late spring and seasonal frost occurs down to a depth of $8 \mathrm{~m}$ on the $\mathrm{N}$ side. Gemsstock is located at the lower fringe of permafrost and is additionally affected by ongoing retreat of the Gurschen glacier on the northern side, which makes it susceptible to rock slope failure (Kenner et al., 2011). 


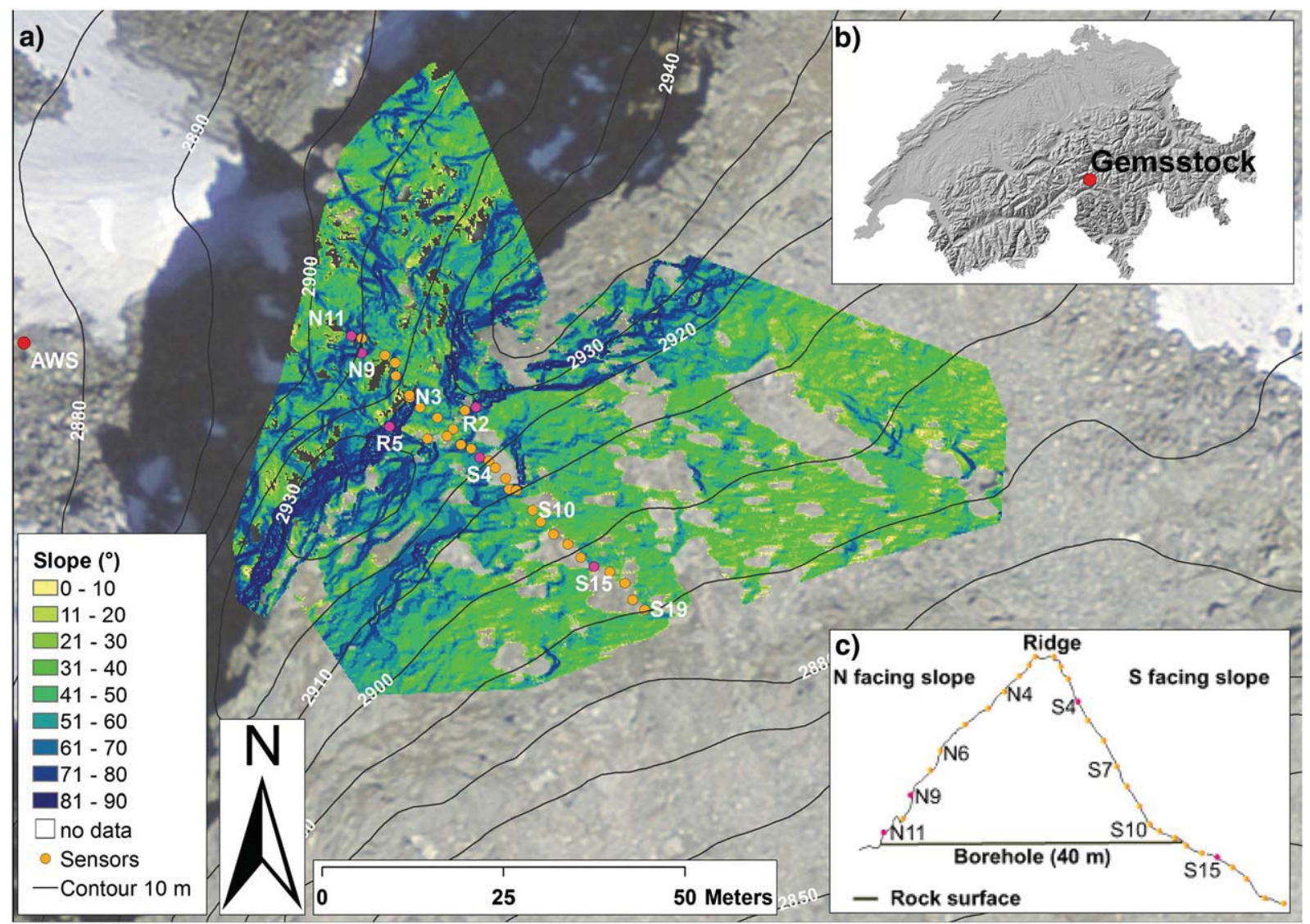

Fig. 1. Overview of the Gemsstock study area: (a) Slope angles obtained from TLS data. The location of the AWS is indicated by a red dot (map data: swissimage@2015 swisstopo 5704000 000). (b) The location of Gemsstock in the Swiss Alps (map data: DHM25 L2@2015 swisstopo 5704000 000). (c) Cross-section of the ridge showing the N and S rock faces and the measurement set-up. Orange dots indicate the NSRT sensor locations and selected labels are shown for better orientation. Sensors discussed in further detail are highlighted in pink. The logger abbreviations are used henceforth in the text and signify: N: loggers in the north slope; S: loggers in the south slope; R: loggers on the ridge.

\section{Methods}

\subsection{Near-surface rock temperature measurements}

To study the spatially variable thermal regime of the rock slopes and measure NSRT, 30 temperature loggers (iButtons) were installed in a linear layout in shallow $0.1 \mathrm{~m}$ horizontal boreholes over the $\mathrm{N}$ and $\mathrm{S}$ facing rock walls with approximately $3 \mathrm{~m}$ vertical spacing. 5 additional temperature devices were installed at the top of the ridge in nearvertical rock, covering various aspects (Fig. 1c).

The coin-sized Maxim iButton ${ }^{\circledR}$ DS1922L operates in a temperature range from $-40{ }^{\circ} \mathrm{C}$ to $+85^{\circ} \mathrm{C}$, with a measurement accuracy of $\pm 0.5^{\circ} \mathrm{C}$ at temperatures between $-10{ }^{\circ} \mathrm{C}$ and $+65{ }^{\circ} \mathrm{C}$ (Maxim Integrated, 2013). After calibration of the temperature loggers in an ice-water bath in a cold laboratory the instrument accuracy is $\pm 0.25{ }^{\circ} \mathrm{C}$ around $0{ }^{\circ} \mathrm{C}$. The open access software iAssist (Keller et al., 2010) was used to deploy and read out the temperature loggers.

To measure continuous NSRT in shallow boreholes at 2-hourly intervals, the temperature loggers were placed in a water resistant plastic capsule to avoid device failure due to water infiltration (Gubler et al., 2011; Lewkowicz, 2008). This causes a short but acceptable delay in the thermal reaction (Haberkorn et al., 2015). In addition, the boreholes were sealed with a gum plug to protect the devices from water, atmospheric influences and the direct exposure to solar radiation. However, 5 devices on the $\mathrm{S}$ face failed during the first year, resulting in only $86 \%$ of valid temperature time series, whereas the data was $100 \%$ complete in the second period. Data gaps of one day occurred during data extraction and were filled using linear interpolation between the nearest data points
All shallow borehole locations have strongly varying local rock and topographic properties, such as slope, aspect and elevation, which were determined by detailed in-situ measurements. Instrument positions were recorded using differential GPS.

\subsection{Snow cover detection on the basis of NSRT}

A sufficiently thick snow cover is a good thermal insulator, damping the influence of air temperature and solar radiation on daily NSRT variations effectively during the snow covered period. This insulating characteristic makes it possible to estimate the presence/absence of a snow cover manually on the basis of each NSRT time series and their daily standard deviation, based on the approach presented in Schmid et al. (2012). Although no direct validation of the snow cover duration is feasible, the applied method is tested for a far wider range of topographic situations here than previously by e.g. Danby and Hik (2007) or Schmidt et al. (2009). Schmid et al. (2012) chose NSRT standard deviation thresholds of $0.1^{\circ} \mathrm{C}$ for positive NSRT, $0.3{ }^{\circ} \mathrm{C}$ for negative NSRT and treated "spurious" gaps with a standard deviation of $\leq 0.5^{\circ} \mathrm{C}$. The proposed thresholds had to be adapted slightly for steep bedrock, since higher NSRT standard deviations (especially for positive NSRT) were observed in the $\mathrm{S}$ face due to strong incoming solar radiation. A uniform threshold of NSRT standard deviation $<0.5^{\circ} \mathrm{C}$ was therefore chosen for both positive and negative NSRT.

In addition, the zero curtain period, which can indicate the occurrence of snowmelt (snowpack isothermal at $0{ }^{\circ} \mathrm{C}$ ) and phase change in the ground, was determined for days with NSRT between $-0.25{ }^{\circ} \mathrm{C}$ and $0.25{ }^{\circ} \mathrm{C}$ (Gubler et al., 2011) at each temperature logger. In the $\mathrm{S}$ face the rock surface temperature generally remains around $0{ }^{\circ} \mathrm{C}$ during 


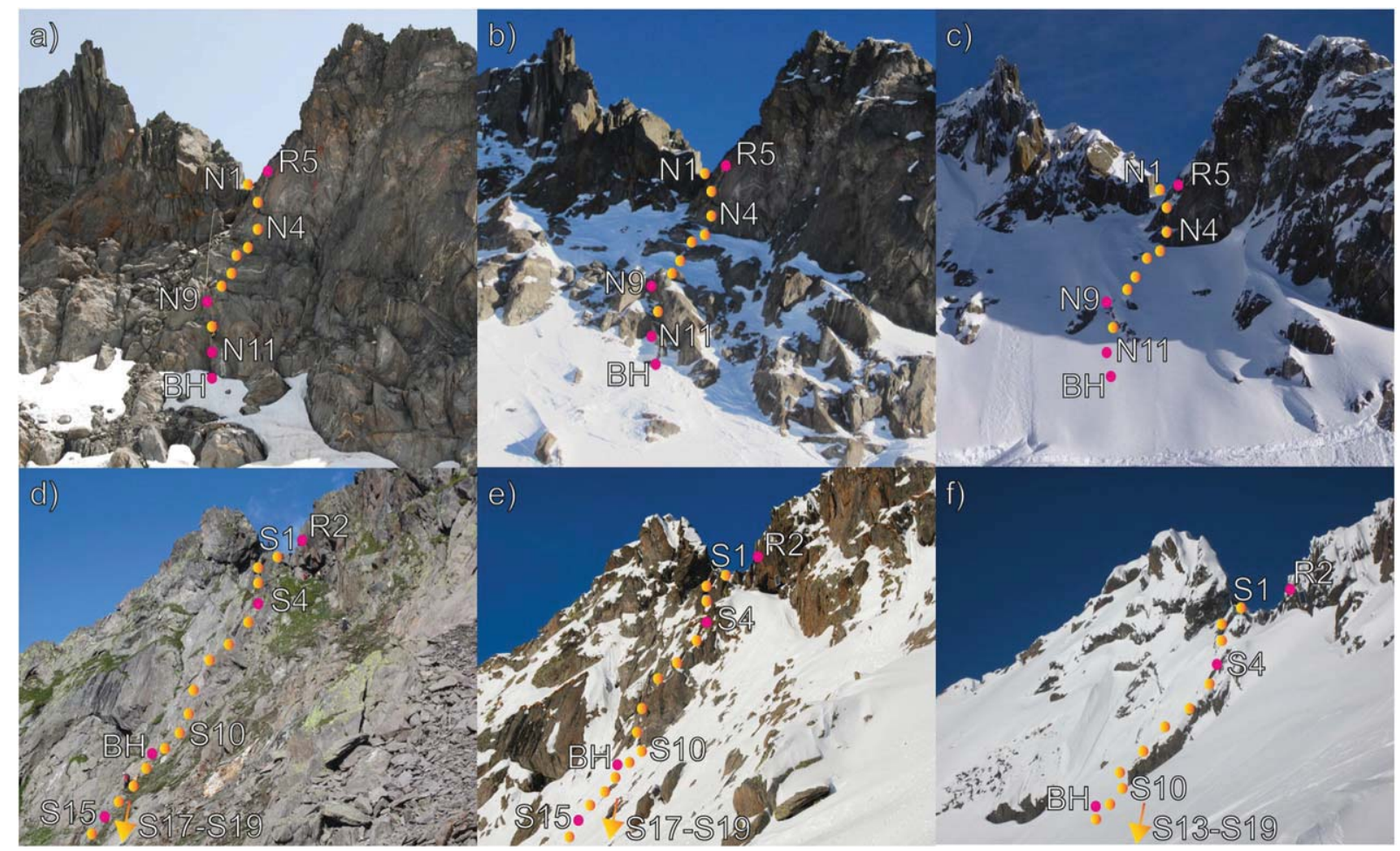

Fig. 2. Photographs of the $\mathrm{N}$ (top) and $\mathrm{S}$ (bottom) facing study slopes, as well as 2 selected loggers on the ridge (R2, R5) at Gemsstock in summer (a, d), late autumn (b, e) and winter (c, f). The locations of all NSRT sensors are marked with orange dots. Pink dots highlight the NSRT sensors selected for detailed analysis, as well as both ends of the borehole (BH). Photographs were taken on 3 August 2013 (a, d), on 9 November 2012 (b, e) and on 28 January 2014 (c, f). Figure adapted from Haberkorn et al. (2015).

the whole snow covered period, thus making it impossible to detect the start of an isothermal snowpack.

\subsection{Terrestrial laser scanning}

The acquisition of high resolution DTMs of the rock surface in summer, but also spatially distributed and non-invasive snow depth data in winter is fundamental in this study and was carried out using TLS. Widespread snow depth data for the entire rock wall was obtained at different stages of the winter on the N and S facing slopes since 2012. Thus the high spatial and temporal variability of snow depth and snow distribution in rock walls is not only available for the instrumented area but also for the wider surroundings.

The Riegl long range laser scanners VZ6000 and LPM321 were used to acquire high resolution point clouds $(<0.2 \mathrm{~m}$ ) from a single scan position, on both the $\mathrm{N}$ and $\mathrm{S}$ side of the snow-free slopes in summer and of the snow surface in winter. The measurements were georeferenced using global coordinates of reflecting benchmarks (further details in Haberkorn et al., 2015).

To obtain HS the shortest distance from each terrain point to the point cloud at the snow surface was calculated with the resolution of the point

Table 1

Overview of the data obtained during the measurement period.

\begin{tabular}{lll}
\hline Date & Year & Data \\
\hline 1 August 2012 to 31 July 2014 & $2012-2014$ & NSRT \\
1 August 2012 to 31 July 2013 & $2012-2013$ & NSRT \\
1 August 2013 to 31 July 2014 & $2013-2014$ & NSRT \\
19 December 2012 & & HS using TLS, snow pits \\
7 June 2013 & & HS using TLS \\
11 December 2013 & & HS using TLS, snow pits \\
28 January 2014 & & HS using TLS, snow pits \\
16 May 2014 & & HS using TLS (S slope only), \\
& & snow pits \\
\hline
\end{tabular}

cloud. Parts of the NSRT measurement line were not visible in the laser scans due to blind areas behind ridges or in locations shadowed by other rocks. To fill HS gaps the closest HS point within a range of $1 \mathrm{~m}$ was appropriated to the NSRT location (Haberkorn et al., 2015).

Terrain roughness, which is defined as the variability of a topographical surface at a given scale (Grohmann et al., 2011) is derived by the vector ruggedness measure developed by Sappington et al. (2007). The terrain roughness is based on changes in slope and aspect derived from the DTM for every $0.2 \mathrm{~m}$ grid cell of the snow free rock walls and the corresponding winter surfaces. Roughness can range from 0 (smooth) to 1 (extremely rough). To assess terrain smoothing processes at the rock wall scale, the degree of attenuation of terrain features produced by snow and the degree of similarity between winter and summer surface are estimated with the coefficient of determination $\mathrm{R}^{2}$ separately for each rock wall (Veitinger et al., 2014).

\subsection{Snow pits}

In-situ snow pit measurements were carried out to obtain detailed information on snow cover characteristics. To account for varying snow conditions in between and over the rock walls, 6 snow pits were distributed over the $\mathrm{N}$ and the $\mathrm{S}$ facing slopes during each field campaign (Table 1). Position, elevation, slope angle and aspect were measured at each snow pit site. Snow cover characteristics were classified according to Fierz et al. (2009). Snow layer thickness, grain type, grain size, hand hardness index, snow density, snow temperature and the temperature at the snow-rock interface were recorded.

\subsection{Multiple linear regression analysis}

The SO is the difference between the mean annual NSRT and the MAAT (Smith and Riseborough, 2002) and is used to explain the interaction between the ground surface temperature regime and the atmosphere and the influence of these on the total energy balance of the 

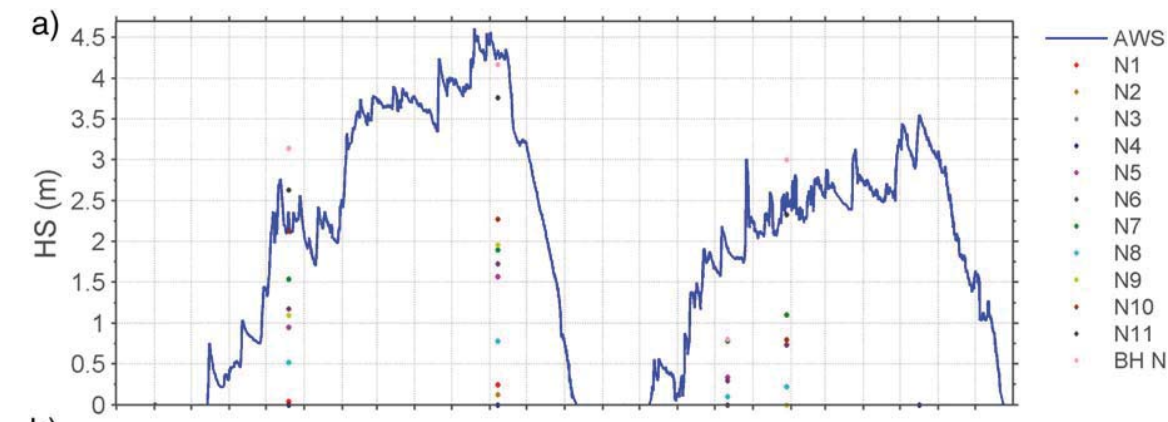

b)

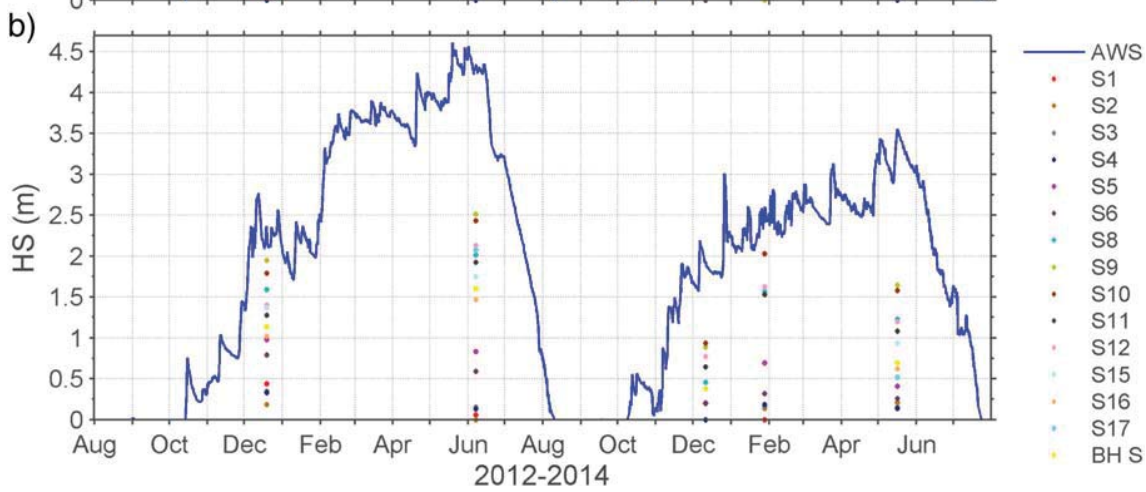

Fig. 3. Snow depth evolution at the AWS Gemsstock (blue line) and the snow depths at the NSRT sensors obtained by TLS in (a) the N and (b) the S facing rock walls (coloured dots). Missing TLS points are due to terrain shading. Gaps and erroneous values in the continuous snow depth series were treated as discussed in Haberkorn et al. (2015).

rock walls. Due to the absence of vegetation or loose rock material in the rock walls, the temperature difference between the air and the ground surface is mostly influenced by snow cover and radiation.

Multiple linear regression models were used to quantify the influence of topographic characteristics, as well as snow depth on the spatial variability of SO at each individual temperature logger for the years 2012-2013 and 2013-2014. The explanatory variables used in the statistics are the mean annual PISR, calculated for each temperature logger location using ArcGIS (CESRI, Redlands, CA, USA), as well as the terrain roughness and the measured mean snow depth per winter season, both derived from TLS. PISR is an indirect measure of the topographic variables aspect, slope and elevation, whereas terrain roughness is responsible for trapping snow and strongly affects the redistribution of snow by wind (Grünewald et al., 2010; Veitinger at al., 2014). The significance of all parameters explaining the regression models were calculated step-wise and only the most significant ones ( $p$-value $<0.05$ ) were selected. Additionally, all input data was normalized to enable a comparison of the importance of each parameter in the model. To examine the model validity of linear regression (independence, normal distribution and constant variance), a Quantile-Quantile plot and Tukey-Ascombe plot of the model residuals (not shown) were analysed.

\section{Results and discussion}

\subsection{Snow cover and surface roughness}

The in-situ snow pit measurements at Gemsstock revealed that the snow cover distribution and characteristics are complex on steep rock walls. The snow surface is strongly influenced by wind erosion and deposition. Sloughing and small avalanches commonly occur during and subsequent to snowfall events - or as a result of warming. On the $\mathrm{N}$ facing rock wall the snow cover typically consists of depth hoar at the base of the snowpack, overlain by faceted crystals. The snowpack is loosely packed with high air contents and is therefore an effective thermal insulator. On the $\mathrm{S}$ side there is often a layer of ice at the base of the snow cover due to infiltration and refreezing of snow melt water. The snow cover mainly consists of densely packed melt forms alternating with hard melt crusts and is hence a better thermal conductor. The variations in thermal resistance of the snow cover between the $\mathrm{N}$ and $\mathrm{S}$ slopes are especially important for snow depths $<0.2 \mathrm{~m}$ (Section 4.5 ).

Over the $\mathrm{N}$ facing scan area, snow depth is uniformly distributed with $\mathrm{HS}$ peaks on slopes between $40^{\circ}$ and $75^{\circ}$ and snow depths between 1.5 and $2.3 \mathrm{~m}$, as shown in Fig. 4a. Snow depths generally decrease on slopes exceeding $75^{\circ}$, except for a peak at $87^{\circ}$ caused by complex micro-topography. In the smooth $\mathrm{S}$ facing slope (Fig. $4 \mathrm{~b}$ ) the maximum HS of 1.5 to $2 \mathrm{~m}$ is found in the moderately steep $30^{\circ}$ to $45^{\circ}$, lower rock wall parts. Here the snow accumulates and gradually covers the steeper and more heterogeneous zones lying above, which is confirmed by a steady decrease of snow depth for slopes $>35^{\circ}$. Snow can accumulate in rock wall sectors exceeding $80^{\circ}$ if the distance to a rock ledge below is short enough. This confirms the findings of Wirz et al. (2011), who suggest that snow accumulates in slopes up to $70^{\circ}$. Snow depth differences between the $\mathrm{N}$ and the $\mathrm{S}$ facing rock wall (Fig. 4) can probably be attributed to the aspect induced variations of snow cover characteristics and consequently of snow settlement and densification, as modelled by Haberkorn et al. (2015). The estimated HS measurement errors when using TLS in steep terrain are in the order of $0.1 \mathrm{~m}$, with a single cell level of significance of $0.08 \mathrm{~m}$ (Haberkorn et al., 2015). TLS is thus suitable to analyse HS in steep rock walls.

The accumulation of relatively large amounts of snow in very steep terrain is only possible due to the fact that the rock walls are considerably rough with terrain roughness ranging from negligibly small to 0.88 . The roughness index clearly shows the different characteristics of the $\mathrm{N}$ and $\mathrm{S}$ slopes: the heterogeneous $\mathrm{N}$ scarp slope has a mean roughness of 0.058 with a STD of 0.110 , compared to a mean roughness of 0.020 with a STD of 0.047 in the more homogeneous S dip slope (Fig. 5a). Terrain roughness is strongly controlled by neighbouring topographic features, like rock ledges (Veitinger et al., 2014) and directly influences the spatial snow distribution, in combination with meteorological factors (e.g. wind). Additionally, it can be presumed that such rough rock surfaces prevent the occurrence of big avalanches in steep terrain, as already observed by Veitinger et al. (2014). A distinctly smoothed winter terrain surface develops on both slopes with increasing snow depths (Fig. 5b, c) resulting in low values of $R^{2}$ between the terrain and snow surface roughness. 

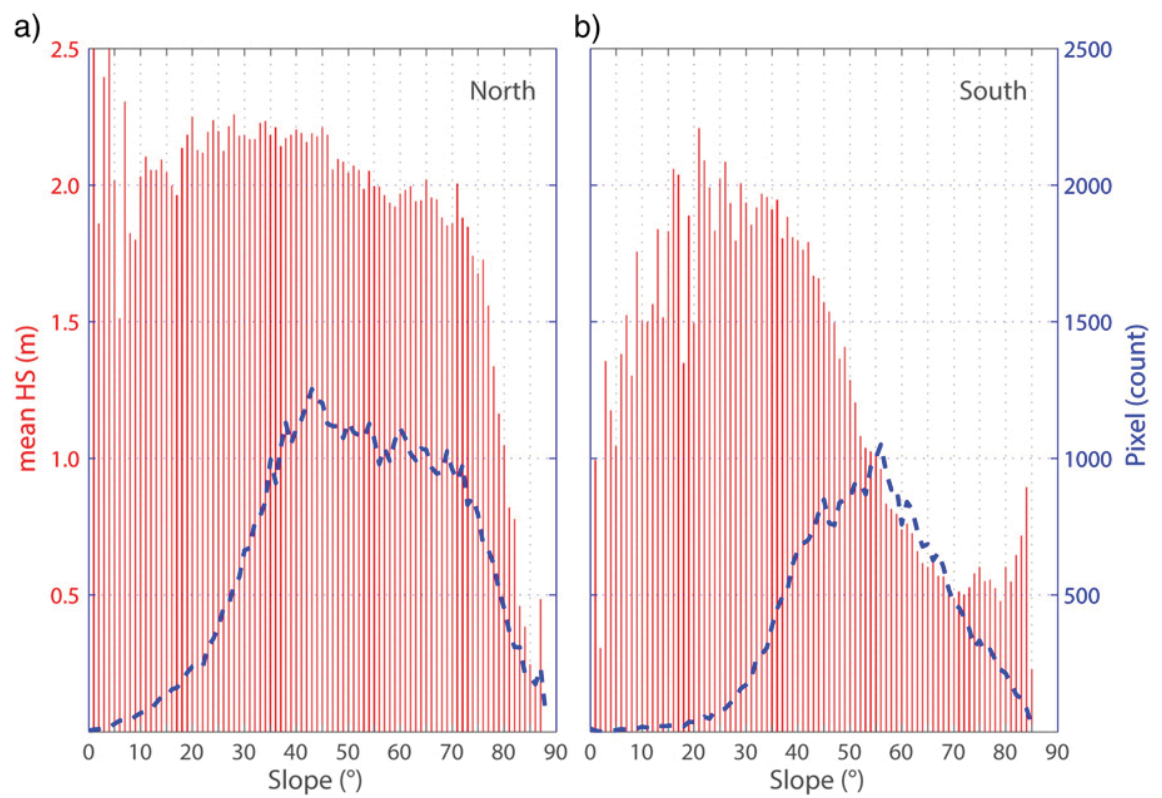

Fig. 4. Mean snow depth (red bars) and areal distribution of snow (blue dashed line) as a function of slope angle for (a) the $\mathrm{N}$ and (b) the S facing slopes. The mean slope angle over both the $\mathrm{N}$ and $\mathrm{S}$ face is $50^{\circ}$.

\subsection{Snow depth at temperature loggers}

In parallel to the HS evolution at the AWS, the snow depths measured at the locations of the temperature loggers on five days during the two winters using TLS (Table 1) are shown in Fig. 3. The snow cover duration, snow depth and consequently its melt regime are heterogeneous in time and space. Snow depth at the AWS in flat terrain significantly deviates from HS observed in the rock walls. No quantitative

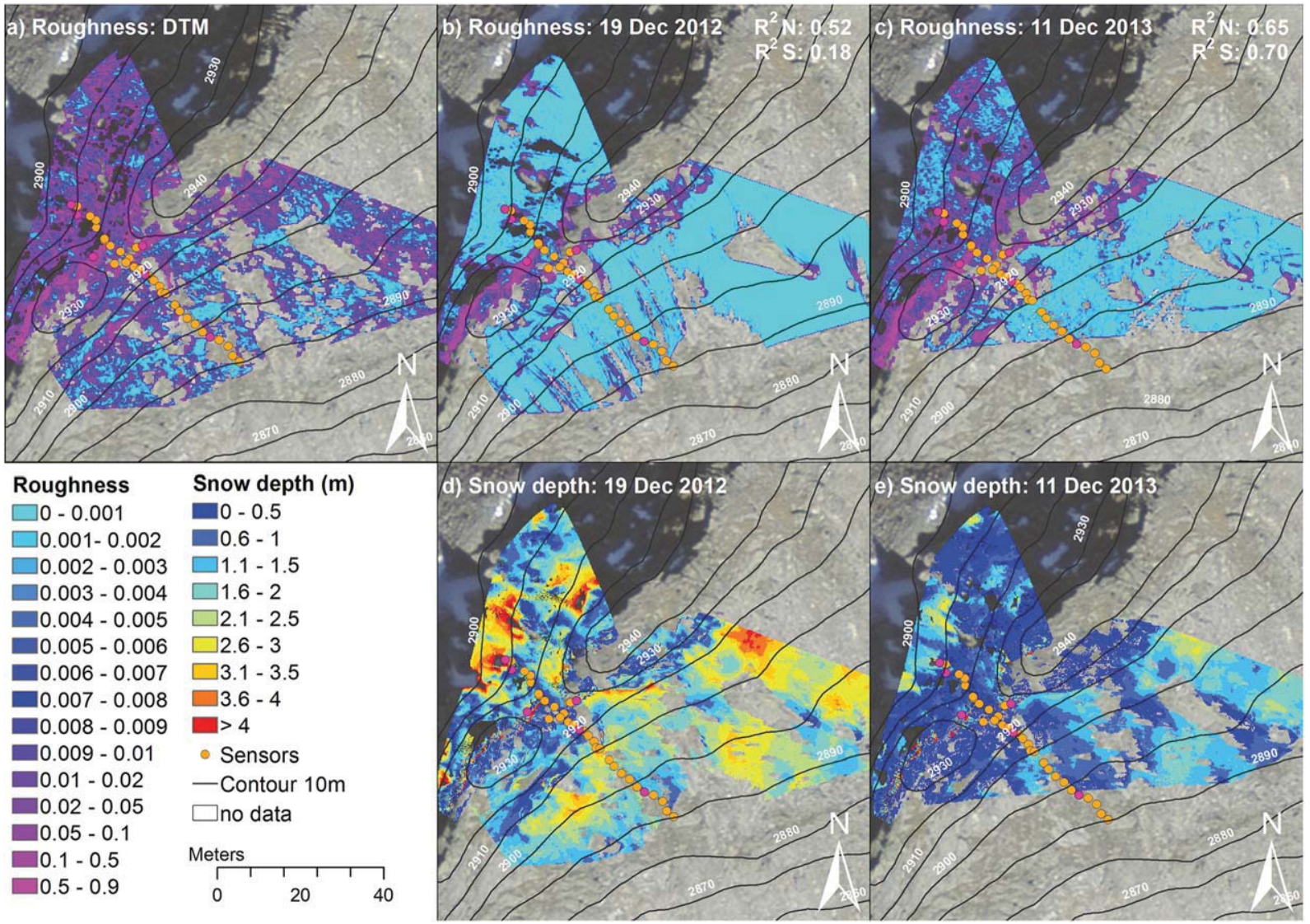

Fig. 5. Surface roughness in summer (a) and winter (b, c) and the corresponding snow depth distribution (d, e) at Gemsstock for two selected TLS dates (19 December 2012 and 11 December 2013) with different snow conditions. The correlation between the snow surface roughness and terrain roughness is shown for both the $N\left(R^{2} N\right)$ and the $S\left(R^{2} S\right)$ facing rock walls in (b) and (c). Orange dots indicate the temperature logger locations and those discussed in detail are marked in pink (map data: swissimage@2015 swisstopo 5704000000 ). 
Table 2

Mean annual NSRT (MNSRT), their standard deviation, mean annual amplitude (MAA) and surface offset (all in ${ }^{\circ} \mathrm{C}$ ) for the entire $\mathrm{N}$ and $\mathrm{S}$ facing slope, as well as for the ridge over the whole investigation period and for the years 2012-2013 and 2013-2014.

\begin{tabular}{|c|c|c|c|c|c|c|c|c|c|c|c|c|}
\hline \multirow[b]{2}{*}{ Location } & \multicolumn{4}{|c|}{1 August 2012-31 July 2014} & \multicolumn{4}{|c|}{1 August 2012-31 July 2013} & \multicolumn{4}{|c|}{1 August 2013-31 July 2014} \\
\hline & MNSRT & STD & MAA & SO & MNSRT & STD & MAA & SO & MNSRT & STD & MAA & SO \\
\hline North & -0.5 & 0.8 & 2.4 & 2.2 & -0.6 & 1.0 & 2.7 & 2.5 & -0.3 & 0.7 & 2.3 & 1.8 \\
\hline South & 3.2 & 0.4 & 1.3 & 5.8 & 3.2 & 0.5 & 1.6 & 6.0 & 3.0 & 0.6 & 2.9 & 5.2 \\
\hline Ridge & 0.3 & 1.7 & 4.1 & 2.9 & -0.1 & 1.7 & 4.2 & 3.1 & 0.5 & 1.7 & 4.1 & 2.7 \\
\hline
\end{tabular}

information on snow settling, avalanching or sloughing is available, making the reconstitution of continuous snow depths in the rock walls on the basis of the HS measured in the flat field impossible. This agrees with results presented by Grünewald and Lehning (2011) for catchment-wide snow distribution. Although similar overall patterns of snow depth and snow distribution are true for the different logger locations, which confirms the findings of Wirz et al. (2011), the small scale variability between the loggers is large. Fig. $5 \mathrm{~d}$, e indicate that the loggers close to both sides of the top of the ridge (N1-N2, S1-S3) are mainly snow free (winter 2013-2014) or only covered by a thin, patchy snow layer (winter 2012-2013), whereas bigger differences in snow cover timing and distribution between the $\mathrm{N}$ and the $\mathrm{S}$ face occur further downslope. A homogeneous and thick snow cover can accumulate on the smooth S slope (loggers S6-S19 with mean HS of 1.3 to $1.8 \mathrm{~m}$ ), whereas the heterogeneous terrain in the $\mathrm{N}$ face leads to stronger variability in snow depths. The locations N8 and N9 accumulate far less snow (mean HS of 0.4 to $0.8 \mathrm{~m}$ ), than N10 and N11 (mean HS of 1.3 to $2.2 \mathrm{~m}$ ), although all locations are over $75^{\circ}$ steep. This is due to strongly varying micro-topographic features, like the distances to underlying flatter rock ledges, on which snow can accumulate (Fig. 2). This micro-topographic effect most likely has a more important influence on snow distribution than slope angle alone. Only loggers located in nearly vertical rock far above ledges are snow free or occasionally covered with rime after storms, as is the case for N3 and N4 and for all loggers on the ridge (R1-R5). Hence, the date of snow disappearance varies between 1 and 4 weeks within a particular rock face.

Snow cover onset, duration and depth do not only vary between the $\mathrm{N}$ and $\mathrm{S}$ slopes, but also between the two winter seasons investigated (Fig. 3). The snow cover onset in the flat rock wall parts was similar (November) in both winters 2012-2013 and 2013-2014, but the initial snow cover was much thicker in winter 2012-2013 (Fig. 5d, e). This resulted in snow free sensors at locations over $3 \mathrm{~m}$ above ledges until the end of December 2013 (e.g. N9, N10). At such exposed locations, as well as at the upper windswept S side (S1-S6), only a thin and patchy snow cover persisted in winter 2013-2014, whereas in winter 2012-2013 a thick snow cover was able to accumulate. This was also reflected in the timing of snow disappearance, which was 2 to 3 weeks earlier in the $S$ face and 2 to 10 weeks earlier in the $\mathrm{N}$ face in winter 2013-2014 than in the previous winter.

\subsection{Local variability of NSRT in the rock wall}

At the local rock wall scale the variability of NSRT (Table 2) and SO (Fig. 6) across the whole N (N1-N11) and S facing (S2-S19) rock walls and the entire ridge (R1-R5) is strong. Mean annual NSRT varies between $-0.5{ }^{\circ} \mathrm{C}$ and $3.2{ }^{\circ} \mathrm{C}$ for both sides of the rock wall. NSRT and consequently the $\mathrm{SO}$ are strongly controlled by solar radiation, especially in snow free locations like the ridge (high STD of mean annual NSRT). In contrast snow onset and depth are the major driving factors of SO in the partly snow covered N and S faces during the years 2012-2013 and 2013-2014. Mean annual NSRT differences of $3.7^{\circ} \mathrm{C}$ between the $\mathrm{N}$ and the $S$ facing rock walls are not as pronounced as would be expected in steep, snow free rock and as were reported by Gruber et al. (2004b) or Hasler et al. (2011), with up to $8{ }^{\circ} \mathrm{C}$ difference. This is due to the accumulation of a thick snow cover in most parts of the rough rock walls at Gemsstock.
The small-scale variability in SO in between the slopes reveal large differences within the more heterogeneous $\mathrm{N}$ facing slope in contrast to the smoother $\mathrm{S}$ facing slope (Table 2, Fig. 6). Differences in mean annual NSRT within a rock face or on the ridge are up to $4.0^{\circ} \mathrm{C}$ and thus $1.5^{\circ} \mathrm{C}$ higher than reported by Gubler et al. (2011) for homogeneous terrain with slope angles below $50^{\circ}$.

To investigate the topographic, spatial and temporal dependence of NSRT, the evolution of the cumulated sum of NSRT separated for the years 2012-2013 (solid line) and 2013-2014 (dashed line) for selected temperature loggers are shown in Fig. 7. Cumulated NSRT were mainly negative in the $\mathrm{N}$ face (Fig. 7a) between January and the end of June, supporting the observation of ice in the $\mathrm{N}$ facing slope. However, cumulated NSRT at temperature logger $\mathrm{N} 11$ was close to $0{ }^{\circ} \mathrm{C}$ during this period, which confirms the absence of permafrost conditions observed at the nearby borehole (Figs. 1c, 2). The topography at the borehole and logger N11 favours an early and thick accumulation of snow (Figs. 2, 3, $5 \mathrm{~d}, \mathrm{e}$ ) due to the vicinity to a distinct rock ledge (Table 3 ), thus insulating the rock beneath. The date of the first significant snowfalls in autumn in combination with micro-topography strongly affects ground temperature evolution. This is displayed by the differing decrease in cumulated NSRT in autumn. In winter 2013-2014 air temperature and hence cumulated NSRTs at snow free locations (R5 in Fig. 7a) were warmer compared to winter 2012-2013. In contrast cumulated NSRTs at snow covered logger locations (N11 in Figs. 7a, 8e) were colder due to the absence of a sufficiently thick and insulating snow cover in the beginning of winter 2013-2014. In the N facing rock wall the warming effect of a thick snow cover (mean HS measured by TLS differing from 0.5 to $2.3 \mathrm{~m}$ ) on NSRT can clearly be observed. The mean annual NSRT of the snow free loggers were around 1.3 to $2.3^{\circ} \mathrm{C}$ colder than the NSRT of the snow covered loggers, which are effectively insulated from cold winter air temperatures.

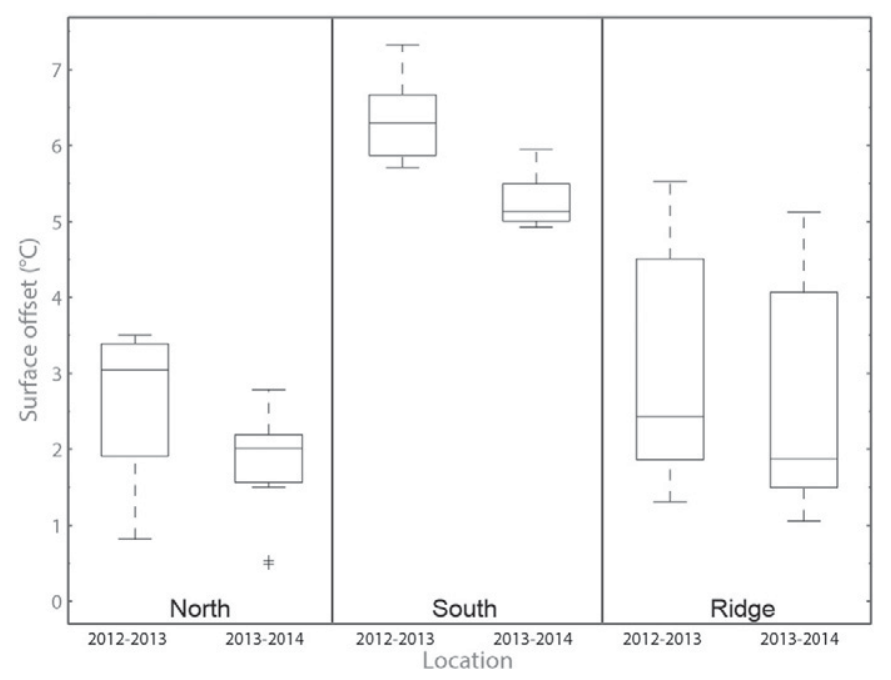

Fig. 6. Surface offset for the years 2012-2013 and 2013-2014 in the N face, the S face and on the ridge. In each box, the median is marked, the box edges are the 25 th and 75 th percentiles, the whiskers extend to the $2.5 \%$ and $97.5 \%$ quantile and outliers $(\mathrm{N} 1, \mathrm{~N} 2)$ are plotted individually as crosses. 

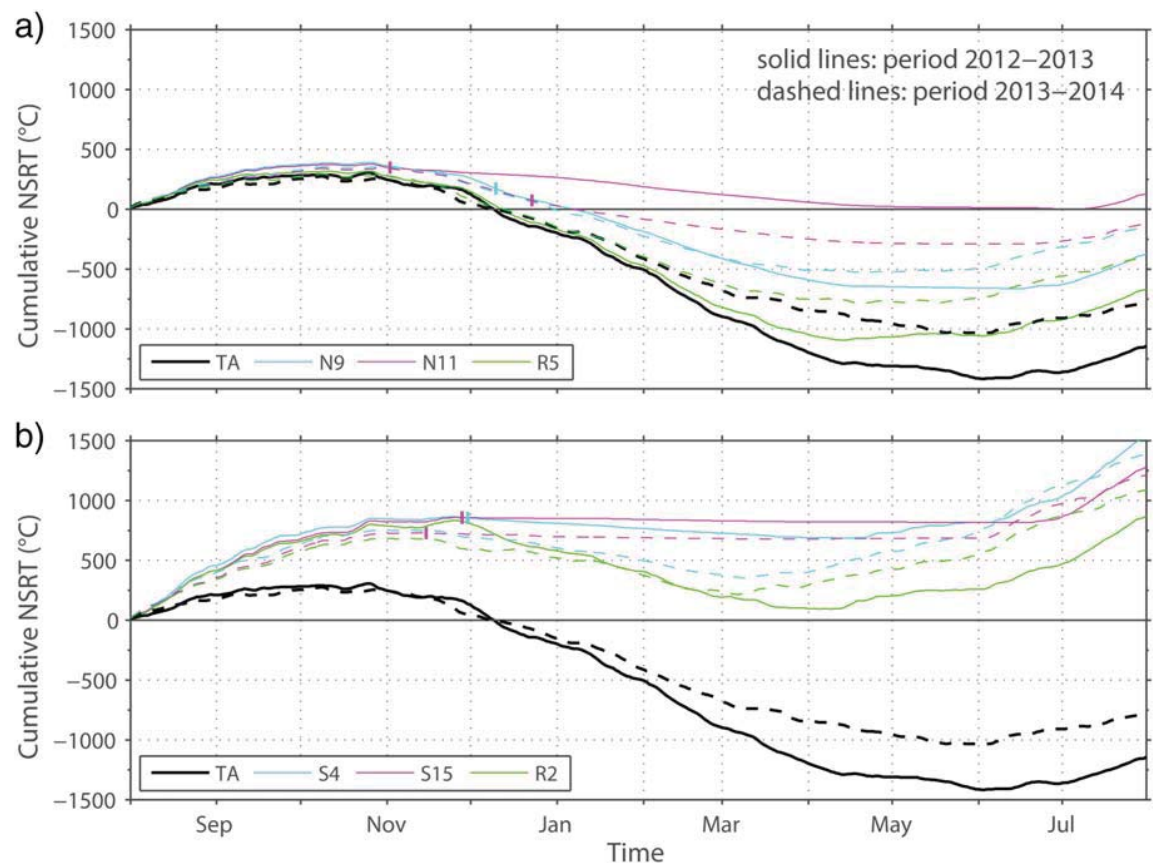

Fig. 7. Cumulative sum of NSRT as a function of time for both years 2012-2013 (solid lines) and 2013-2014 (dashed lines) for (a) the N and (b) the S facing rock slopes and selected loggers on the ridge. To facilitate visualization only a selection of representative temperature loggers is shown. Loggers R5 and R2 represent snow free, loggers N11 and S15 snow covered and loggers N9 and S4 ephemeral snow cover conditions. The $0{ }^{\circ} \mathrm{C}$ isotherm is illustrated by a grey horizontal line. The snow onset is highlighted by a vertical tag for temperature loggers accumulating snow throughout the winters. The colours of the tags represent the appropriate logger colours.

In the $\mathrm{S}$ facing slope cumulated NSRT (Fig. 7b) exceeding $0{ }^{\circ} \mathrm{C}$ confirm the absence of permafrost, which is in accordance with borehole temperatures. At most snow covered loggers (see S15 in Fig. 7b) no temperature decrease is evident in autumn, with constant cumulated NSRT during the whole snow covered period. The snow free loggers ( $R 2$ and S4 only in winter 2013-2014 in Fig. 7b) only show a slight temperature decrease in autumn, since steep $\mathrm{S}$ facing slopes receive more direct solar radiation, the lower the angle of the incoming solar radiation. There was no obvious cooling effect induced by the thick snow cover (mean HS from 0.5 to $1.8 \mathrm{~m}$ ) persisting from November to June in the $\mathrm{S}$ facing slope. Beside the lower cumulated NSRT (R2 in Fig. 7b), also the mean annual NSRT (Table 3) of the snow free logger R2 is up to $1.2^{\circ} \mathrm{C}$ colder compared to the snow covered logger (S15), which differs from the assumptions of Magnin et al. (2015). The latter reported a cooling effect of thick snow in sunny rock faces, possibly due to the higher surface albedo caused by the presence of snow during much of the year and melt energy consumption. However, these authors estimated snow depths qualitatively, rather than quantitatively. At Gemsstock a cooling effect is evident from mid-March onwards for the months with most intense solar radiation. This is confirmed by a steeper temperature rise of the logger lacking snow (R2) compared to constant cumulated NSRT of the loggers with snow, where solar radiation is blocked (Fig. 7b).

\subsection{Multiple linear regression analysis}

The dependence of topographic characteristics, as well as snow depth on the surface offset and thus on the local NSRT variability was tested using multiple linear regression. An iterative, step wise model reduction computed using the Matlab ${ }^{\circledR}$ Statistics and Machine Learning Toolbox ${ }^{\mathrm{TM}}$ led to the models summarized in Table 4 for the entire rock wall and for the individual $\mathrm{N}$ and $\mathrm{S}$ facing slopes. The major explanatory variable for the surface offset is, as expected, the highly significant variable PISR $\left(\mathrm{p}<1 \times 10^{-6}\right)$ due to the varying aspects. Modelling the dependence of SO on the strongly varying HS showed a significant influence of HS during the snow rich winter 2012-2013, while SO is independent of snow depth during the winter 2013-2014, when less snow accumulated. Terrain roughness proves to be non-explanatory. PISR and snow depth could explain $77 \%$ of the surface offset variability in the year 2012-2013, while $72 \%$ of the SO variability could be explained by PISR in 2013-2014. The results confirm solar radiation and the associated topography as being the dominating factors on the surface offset.

Considering the single rock slopes results in the sole dependence of SO on snow depth $(\mathrm{p}<0.05)$ in $2012-2013$, since the influence of PISR is omitted due to the separation between the $\mathrm{N}$ and the $\mathrm{S}$ facing rock

Table 3

Aspect, slope, distance to the rock ledge below (DRLB), mean annual near-surface rock temperature (MNSRT), surface offset , the mean annual correlation of NSRT and air temperature $\left(\mathrm{R}^{2}\right)$, mean annual snow depth (MHS) and snow cover duration (Duration) for selected temperature loggers with different snow conditions for the years $2012-2013$ and $2013-2014$.

\begin{tabular}{|c|c|c|c|c|c|c|c|c|c|c|c|c|c|}
\hline \multirow[b]{2}{*}{ Logger } & \multirow[b]{2}{*}{$\begin{array}{l}\text { Aspect } \\
\left({ }^{\circ}\right)\end{array}$} & \multirow[b]{2}{*}{$\begin{array}{l}\text { Slope } \\
\left({ }^{\circ}\right)\end{array}$} & \multirow[b]{2}{*}{$\begin{array}{l}\text { DRLB } \\
(\mathrm{m})\end{array}$} & \multicolumn{5}{|c|}{1 August 2012-31 July 2013} & \multicolumn{5}{|c|}{1 August 2013-31 July 2014} \\
\hline & & & & $\begin{array}{l}\text { MNSRT } \\
\left({ }^{\circ} \mathrm{C}\right)\end{array}$ & $\begin{array}{l}\text { SO } \\
\left({ }^{\circ} \mathrm{C}\right)\end{array}$ & $\begin{array}{l}\mathrm{R}^{2} \\
(\%)\end{array}$ & $\begin{array}{l}\text { MHS } \\
(\mathrm{m})\end{array}$ & $\begin{array}{l}\text { Duration } \\
\text { (month) }\end{array}$ & $\begin{array}{l}\text { MNSRT } \\
\left({ }^{\circ} \mathrm{C}\right)\end{array}$ & $\begin{array}{l}\text { SO } \\
\left({ }^{\circ} \mathrm{C}\right)\end{array}$ & $\begin{array}{l}\mathrm{R}^{2} \\
(\%)\end{array}$ & $\begin{array}{l}\text { MHS } \\
(\mathrm{m})\end{array}$ & $\begin{array}{l}\text { Duration } \\
\text { (month) }\end{array}$ \\
\hline R5 & 332 & 72 & 20 & -1.8 & 1.3 & 0.85 & 0 & 0 & -1.1 & 1.1 & 0.83 & 0 & 0 \\
\hline N9 & 340 & 80 & 9 & -1.0 & 2.1 & 0.77 & 1.5 & 6 & -1.4 & 0.8 & 0.79 & 0 & Patchy \\
\hline N11 & 349 & 89 & 3 & 0.4 & 3.5 & 0.52 & 3.2 & 8.5 & -0.3 & 1.8 & 0.59 & 1.2 & 6.5 \\
\hline $\mathrm{R} 2$ & 164 & 58 & 15 & 2.4 & 5.5 & 0.82 & 0 & 0 & 3.0 & 5.1 & 0.74 & 0 & 0 \\
\hline S4 & 122 & 60 & 0 & 4.2 & 7.3 & 0.62 & 0.3 & 4.5 & 3.8 & 6.0 & 0.7 & 0.1 & Patchy \\
\hline S15 & 184 & 53 & 1.5 & 3.5 & 6.7 & 0.5 & 1.6 & 7 & 3.3 & 5.5 & 0.6 & 0.9 & 6 \\
\hline
\end{tabular}



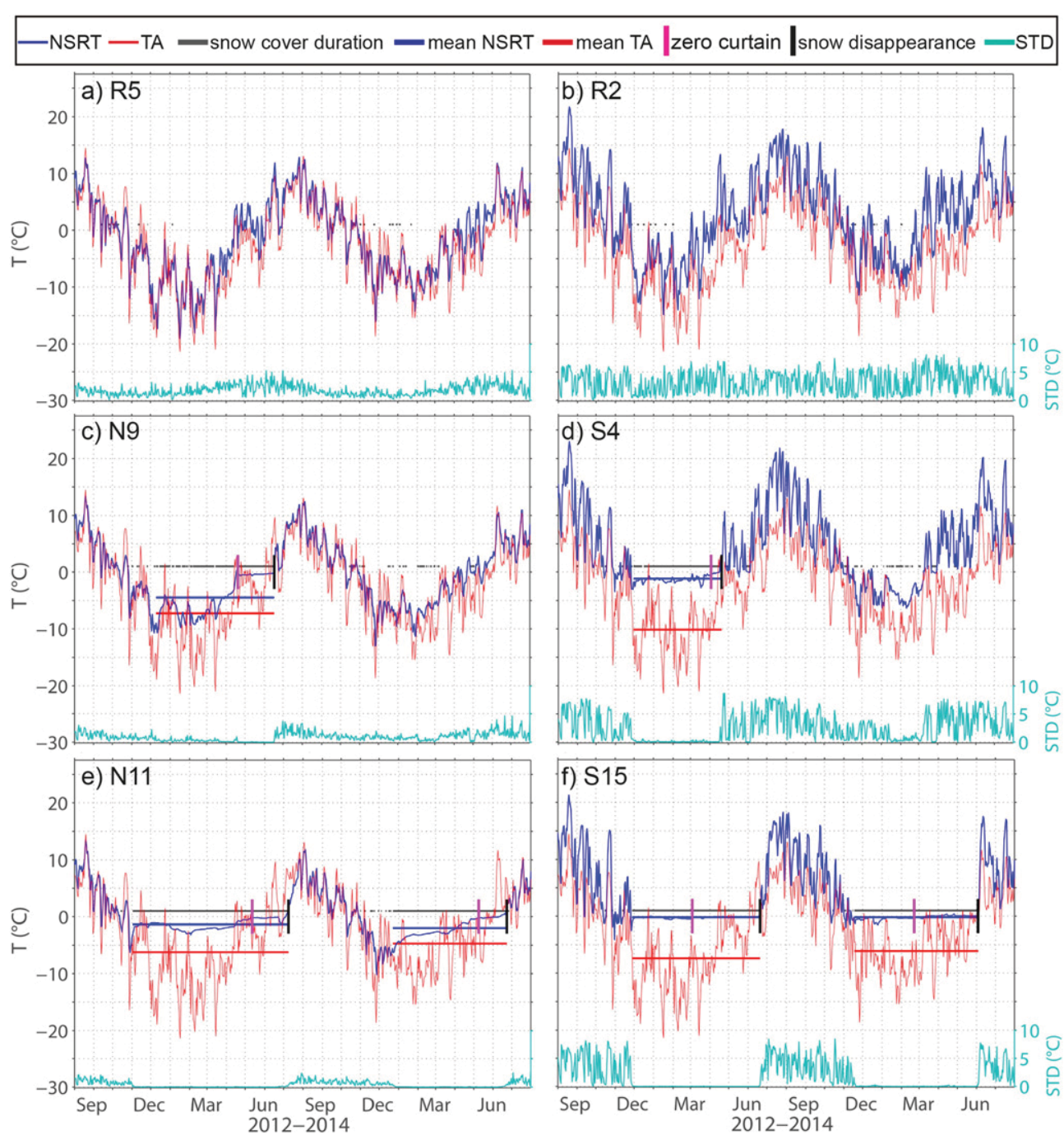

Fig. 8. Daily means of near-surface rock and air temperature between 1 August 2012 and 31 July 2014, as well as the snow cover duration based on daily NSRT standard deviations, the mean NSRT and the mean TA (horizontal bars) for the snow covered periods of the winters 2012-2013 and 2013-2014, the start of the zero curtain period and the day of snow disappearance for the $\mathrm{N}$ (left) and $\mathrm{S}$ (right) facing slopes and selected loggers on the ridge.

slopes. Hence, the models for both the $\mathrm{N}$ and the $\mathrm{S}$ facing slopes in $2013-$ 2014 are not significant. The model for the $S$ facing slope can explain $68 \%$ of the surface offset variability and therefore performs much better than the model of the complex $N$ facing slope ( $R^{2}$ of $46 \%$ ).

The model assumptions for multiple linear regression were fulfilled. Although small deviations from the normal distribution of residuals are obvious, residual analysis confirms the model validity.

\subsection{Variability of NSRT at selected loggers}

The NSRT evolution and the snow cover duration at 6 selected temperature logger locations are presented in Fig. 8 for the $\mathrm{N}$ and the $\mathrm{S}$ facing rock walls. The logger locations have different snow conditions and are thus representative for the majority of conditions observed in the rock walls.

The NSRT evolution at logger locations with a lack of snow follows air temperature in shaded rock faces (R5 in Fig. 8a), whereas pronounced daily temperature amplitudes are registered by loggers exposed to the sun ( $\mathrm{R} 2$ in Fig. 8b). These differences can be expressed in the surface offset. SO only reaches $1.3^{\circ} \mathrm{C}$ in the case of the $\mathrm{N}$ facing loggers and air and rock temperatures are highly correlated with $\mathrm{R}^{2}$ of up to 0.85 (R5 in Table 3). In contrast, the surface offset is up to $5.5^{\circ} \mathrm{C}$ in the $\mathrm{S}$ facing rock wall, confirming incoming solar radiation as a dominant driving factor. The NSRT differences between $\mathrm{N}$ and

\section{Table 4}

Multiple regression models for the entire rock wall $\left(N+S+R\right.$ ), as well as for the $N$ and the $S$ facing rock walls separately. The performance of the model $R^{2}$, the adjusted $R^{2}$ ( $R^{2}$ adj) and the $\mathrm{p}$-value ( $\mathrm{p}$ ) for the F-test on the model are shown for each valid model. $\mathrm{SO}_{\mathrm{i}}$ is the surface offset, $\mathrm{HS}_{\mathrm{i}}$ the snow depth, PISR $\mathrm{R}_{\mathrm{i}}$ the potential incoming solar radiation and $\mathrm{E}_{\mathrm{i}}$ the residuals at each temperature logger i.

\begin{tabular}{|c|c|c|c|c|c|}
\hline Area & Year & Model & $\mathrm{R}^{2}$ & $\mathrm{R}_{\text {adj }}^{2}$ & $\mathrm{p}$ \\
\hline $\mathrm{N}+\mathrm{S}+\mathrm{R}$ & 2012-2013 & $\mathrm{SO}_{\mathrm{i}}=0.0446+0.3513 \times \mathrm{HS}_{\mathrm{i}}+0.6957 \times \mathrm{PISR}_{\mathrm{i}}+\mathrm{E}_{\mathrm{i}}$ & 0.77 & 0.74 & $7.9 \times 10^{-6}$ \\
\hline $\mathrm{N}+\mathrm{S}+\mathrm{R}$ & $2013-2014$ & $\mathrm{SO}_{\mathrm{i}}=0.0002+0.8150 \times \mathrm{PISR}_{\mathrm{i}}+\mathrm{E}_{\mathrm{i}}$ & 0.72 & 0.7 & $1.8 \times 10^{-7}$ \\
\hline $\mathrm{N}$ & $2012-2013$ & $\mathrm{SO}_{\mathrm{i}}=0.5619+0.7630 \times \mathrm{HS}_{\mathrm{i}}+\mathrm{E}_{\mathrm{i}}$ & 0.46 & 0.41 & 0.015 \\
\hline $\mathrm{N}$ & 2013-2014 & Not significant & - & - & 0.4988 \\
\hline S & $2012-2013$ & $\mathrm{SO}_{\mathrm{i}}=-0.2231-0.8273 \times \mathrm{HS}_{\mathrm{i}}+\mathrm{E}_{\mathrm{i}}$ & 0.68 & 0.62 & 0.022 \\
\hline S & 2013-2014 & Not significant & - & - & 0.8851 \\
\hline
\end{tabular}


$\mathrm{S}$ are even more pronounced in steep slopes, due to the fact that steep $\mathrm{N}$ facing slopes receive almost no direct solar radiation in winter, in contrast to $S$ facing slopes. The topography driven difference in mean annual NSRT of $4.2^{\circ} \mathrm{C}$ (R2 and R5 in Table 3 ) between the $\mathrm{N}$ and $\mathrm{S}$ facing rock walls agrees with the results of Gubler et al. (2011) for slope angles $>40^{\circ}$.

At rock wall locations with a thick snow cover (mean HS $>1 \mathrm{~m}$ ) the NSRT evolution is strongly controlled by snow. Daily NSRT variations cease in November-December after the first large snowfalls. In the $\mathrm{N}$ facing slope NSRT oscillations are damped and lagged in time in comparison with air temperature (N11 in Fig. 8e). In the S facing slope NSRT remain close to $0{ }^{\circ} \mathrm{C}$ (S15 in Fig. 8f), indicating the absence of permafrost and the release of latent heat during freezing. The rock surface is decoupled from atmospheric influences in both the $\mathrm{N}$ and the $\mathrm{S}$ facing rock walls, resulting in smaller mean annual NSRT differences (N11 and S15 in Table 3). The timing of snow disappearance is around 3 weeks earlier in the $S$ facing rock wall due to stronger insolation. However, the start of snow melt around mid-May is delayed by approximately 2.5 months in the $\mathrm{N}$ face compared to the $\mathrm{S}$ face where a $0{ }^{\circ} \mathrm{C}$ isothermal snowpack is likely to exist since the beginning of March. Inter-annual atmospheric variations also influence the rock surface. In winter 2013-2014 the snow cover onset was 1.5 months later in the $\mathrm{N}$ facing slope than in winter 2012-2013, causing NSRT to decrease in response to cold winter air temperatures. The colder NSRT persisted throughout the winter 2013-2014 under a thick snowpack, although the mean air temperature was $1.6{ }^{\circ} \mathrm{C}$ warmer in winter 2013-2014 than in winter 2012-2013 (blue and red bars in Fig. 8e, N11 in Table 3). This phenomenon underlines the importance of the initial timing and depth of the snow cover and supports results modelled by Luetschg et al. (2008), who reported a $0.5{ }^{\circ} \mathrm{C}$ lower MAGST due to a 1 month delay in snow cover onset.

The inter-annual variations of the snow cover were even more pronounced in steep rock wall sectors far above rock ledges $(>9 \mathrm{~m})$. The snow depths varied from moderately thick in winter 2012-2013 to thin and ephemeral in winter 2013-2014 (N9 and S4 in Fig. 8c, d). The short snow cover durations in winter 2013-2014 caused the mean annual NSRT to decrease by up to $0.4^{\circ} \mathrm{C}$ in both the shaded and sun-exposed slopes (N9 and S4 in Table 3) due to the absence of an insulating snow cover. In particular, in the $S$ facing slope the lack of snow for the months with most intense solar radiation (March to June) resulted in an earlier and stronger temperature increase compared to winter 2012-2013 (S4 in Fig. 7b). These observations confirm results shown in Section 4.3.

The strong small-scale variability in the distributed rock temperature data due to the strongly variable snow cover accumulation in the rock walls results in mean daily temperature gradients up to $10^{\circ} \mathrm{C}$ over only a few metre distance $(6 \mathrm{~m})$. This reveals the heterogeneity and complexity of thermal processes occurring in rough terrain.

In order to assess the onset of the insulating effect of snow in steep rock walls, the daily amplitude of NSRT at each logger and the corresponding snow depth derived by TLS are shown in Fig. 9. Daily amplitudes vary between 0.2 and $11.5^{\circ} \mathrm{C}$ for snow depths $<0.2 \mathrm{~m}$. Daily NSRT amplitudes cease below $0.4{ }^{\circ} \mathrm{C}$ for snow depths exceeding $0.2 \mathrm{~m}$. Thus, it can be assumed that steep rock is effectively insulated from heat loss in winter for snow depths $>0.2 \mathrm{~m}$. Snow pits carried out in the $\mathrm{N}$ facing slope revealed low snow densities of 200 to $250 \mathrm{~kg} \mathrm{~m}^{-3}$, which result in low thermal conductivities ranging from 0.1 to $0.15 \mathrm{~W} \mathrm{~m}^{-1} \mathrm{~K}^{-1}$ (Sturm et al., 1997; Williams and Smith, 1989). Consequently, the heat exchange between the snow and ground surface decreases strongly. In contrast to our findings, the insulation effect of snow previously reported for flat and blocky terrain starts at HS $>0.6-0.8 \mathrm{~m}$ (Keller and Gubler, 1993; Luetschg et al., 2003; Matsuoka and Sakai, 1999; Zhang et al., 2001). The significant differences in insulation threshold depth of the snow cover between the blocky, heterogeneous terrain and a bare, steep rock surface are due to the pronounced surface roughness of the former.

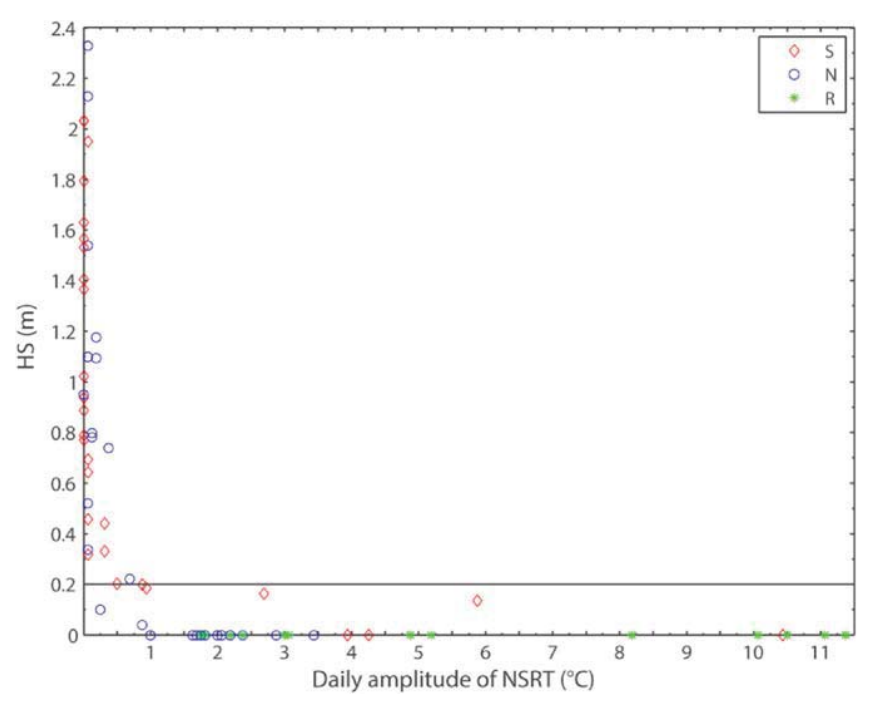

Fig. 9. Relationship between the daily amplitude of NSRT and the corresponding snow depth (HS) measured using TLS at 3 different dates in winter (19 December 2012, 11 December 2013, 28 January 2014). Snow depths measured in spring and the corresponding NSRT are not considered due to temperature bias induced by the zero curtain effect. The onset of an insulating effect of snow depth on NSRT is clearly visible at HS of $0.2 \mathrm{~m}$ (grey horizontal line).

The effects of differences in snow cover characteristics are made evident on the $\mathrm{N}$ and $\mathrm{S}$ facing rock slopes, as discussed in Section 4.1. In the $\mathrm{S}$ slope the thermal conductivity is higher due to a denser snowpack $\left(300-350 \mathrm{~kg} \mathrm{~m}^{-3}\right)$. Consequently the initial insulation of the ground is found for slightly higher snow depths here (Fig. 9). The $0.2 \mathrm{~m}$ insulation threshold for rock faces is crucial, since it is widely assumed that a snow cover $<0.6 \mathrm{~m}$ has a cooling effect on rock temperatures due to an increase of surface albedo, as well as an insufficient thermal resistance of the snow (Keller and Gubler, 1993). Our observations at Gemsstock, but also in the $60^{\circ}$ to vertical and approximately $450 \mathrm{~m}$ high northeast and north-west facing rock walls at Jungfraujoch, Bernese Alps, Switzerland (unpublished) show that snow depths between 0.2 and $0.6 \mathrm{~m}$ can accumulate in steep rock with moderate rock ledges. An insulating effect of rock temperatures due to snow depth exceeding $0.2 \mathrm{~m}$ is likely to exist in such steep and particular high rock walls.

\section{Conclusions and outlook}

In this study moderately steep to vertical $\mathrm{N}$ and $\mathrm{S}$ facing rock walls accumulated considerable amounts of snow (up to $2.3 \mathrm{~m}$ ). Snow distribution was strongly controlled by micro-topographical factors like surface roughness and the presence of distinct ledges alternating with steep to vertical terrain sectors. The snow characteristics, its temporal evolution, spatial distribution and depth influence the rock thermal regime. The main findings of this study are:

Maximum snow depths between 1.5 and $2 \mathrm{~m}$ accumulate on $60^{\circ}$ to $75^{\circ}$ steep, rough slopes with ledges. Snow depth decreases on slopes exceeding $75^{\circ}$. However, snow can also persist in near-vertical terrain if there are ledges up to $9 \mathrm{~m}$ below.

Preferential snow deposition in the rock walls occurs, with similar patterns of snow depth and distribution from year to year. The small scale variability in snow cover onset, melt out and depth is large, resulting in large differences in daily mean rock temperatures up to $10{ }^{\circ} \mathrm{C}$ over short distances $(6 \mathrm{~m})$.

The warming effect $\left(1.3\right.$ to $2.3^{\circ} \mathrm{C}$ ) of thick snow on NSRT in the N facing slope and the persistence of snow during the months with most intense solar radiation in both the $\mathrm{N}$ and the $\mathrm{S}$ facing rock walls results in a difference of only $4{ }^{\circ} \mathrm{C}$ in mean annual NSRT between the $\mathrm{N}$ and $\mathrm{S}$ slopes. This underlines the importance of snow depth and duration for the existence of permafrost in mountain rock walls. 
Up to $77 \%$ of the variability of the surface offset could be explained using multiple linear regression. Incoming solar radiation and thus topography, as well as snow cover (if the snow depth is sufficiently thick and homogeneously distributed) are the dominant factors driving NSRT in the rock walls.

The start of the insulation effect of NSRT induced by snow is observed for snow depths exceeding $0.2 \mathrm{~m}$ in steep, bare rock. This is approximately 0.4 to $0.6 \mathrm{~m}$ less snow than previously observed in flat blocky terrain, due to strongly variable surface roughness. The snow cover properties and their differences in the $\mathrm{N}$ and the $\mathrm{S}$ facing rock slopes have an influence on NSRT when snow depths are below $0.2 \mathrm{~m}$. When they exceed $0.2 \mathrm{~m}$, snow depth is the major factor controlling the thermal regime.

Our measurements show strong variability of NSRT over short distances within a rock face and over varying aspects. Although our results were only observed on the local rock wall scale, our findings are probably valid for other steep, fractured rock walls, which are abundant in the Alps. In addition, the importance of the inter-annual variability of the snow cover could be shown, although only 2 years of data are presented. However, meteorological and snow cover conditions can vary much more strongly than observed during this period.

Knowledge of the interaction between the snow and the rock thermal regime in steep rock is essential for modelling snow cover and rock temperatures in highly complex and variable terrain. Our results will be used to test the applicability of distributed, physically based models and to calibrate these when calculating the thermal effect of snow cover on steep bedrock at a small scale.

\section{Acknowledgements}

This project was funded by the Swiss National Science Foundation (DACH Project no. 200021E-135531). We thank our project partners Michael Krautblatter, Daniel Dräbing and Stephan Gruber. Carlo Danioth and Team at Gemsstock, the SLF Electronics, IT and Mechanics teams, Marc-Olivier Schmid, Lisa Dreier, Martina Sättele and Fabienne Stucki all provided valuable support in the field and with the development of measurement devices. Michael Lehning, Walter Steinkogler, Thomas Grünewald, Benno Staub, Andreas Hasler and Matthias Keller are thanked for their support with data analysis and software.

\section{References}

Armstrong, R.L., Brun, E. (Eds.), 2008. Snow and Climate: Physical Processes, Surface Energy Exchange and Modeling. Cambridge University Press, Cambridge (256 pp).

Blöschl, G., Kirnbauer, R., 1992. An analysis of snow cover patterns in a small alpine catchment. Hydrol. Process. 6, 99-109. http://dx.doi.org/10.1002/hyp.3360060109.

Danby, R.K., Hik, D.S., 2007. Responses of white spruce (Picea glauca) to experimental warming at a subarctic alpine treeline. Glob. Chang. Biol. 13, 437-451. http://dx.doi. org/10.1111/j.1365-2486.2006.01302.x.

Deems, J.S., Painter, T.H., Finnegan, D.C., 2013. Lidar measurement of snow depth: a review. J. Glaciol. 59, 467-479. http://dx.doi.org/10.3189/2013JoG12J154.

Deline, P., Gardent, M., Magnin, F., Ravanel, L., 2012. The morphodynamics of the Mont Blanc massif in a changing cryosphere: a comprehensive review. Geogr. Ann., Ser. A 94, 265-283. http://dx.doi.org/10.1111/j.1468-0459.2012.00467.x.

Fierz, C., Lehning, M., 2001. Assessment of the microstructure based snow-cover model SNOWPACK: thermal and mechanical properties. Cold Reg. Sci. Technol. 33, 123-131. http://dx.doi.org/10.1016/S0165-232X(01)00033-7.

Fierz, C., Armstrong, R.L., Durand, Y., Etchevers, P., Greene, E., McClung, D.M., Nishimura, K., Satyawali, P.K., Sokratov, S.A., 2009. The international classification of seasonal snow on the ground. IHP-VII Technical Documents in Hydrology $\mathrm{N}^{\circ}$ 83, IACS Contribution $\mathrm{N}^{\mathrm{O}} 1$. UNESCO-IHP, Paris (80 pp.).

Grohmann, C., Smith, M., Riccomini, C., 2011. Multiscale analysis of topographic surface roughness in the Midland Valley, Scotland. IEEE Trans. Geosci. Remote Sens. 49, 1200-1213. http://dx.doi.org/10.1109/TGRS.2010.2053546.

Gruber, S., Haeberli, W., 2007. Permafrost in steep bedrock slopes and its temperaturerelated destabilization following climate change. J. Geophys. Res. 112, F02S18. http://dx.doi.org/10.1029/2006JF000547.

Gruber, S., Peter, M., Hoelzle, M., Woodhatch, I., Haeberli, W., 2003. Surface temperatures in steep alpine rock faces - a strategy for regional-scale measurement and modelling. In: Phillips, M., Springman, S., Arenson, L. (Eds.), Proceedings of the 8th International Conference on Permafrost. Swets \& Zeitlinger, Lisse, pp. 325-330.
Gruber, S., Hoelzle, M., Haeberli, W., 2004a. Permafrost thaw and destabilization of Alpine rock walls in the hot summer of 2003. Geophys. Res. Lett. 31, L13504. http://dx.doi. org/10.1029/2004GL020051.

Gruber, S., Hoelzle, M., Haeberli, W., 2004b. Rock-wall temperatures in the Alps: modelling their topographic distribution and regional differences. Permafr. Periglac. Process. 15, 299-307. http://dx.doi.org/10.1002/ppp.501.

Grünewald, T., Lehning, M., 2011. Altitudinal dependency of snow amounts in two small alpine catchments: can catchment-wide snow amounts be estimated via single snow or precipitation stations? Ann. Glaciol. 52, 153-158. http://dx.doi.org/10.3189/ 172756411797252248

Grünewald, T., Schirmer, M., Mott, R., Lehning, M., 2010. Spatial and temporal variability of snow depth and ablation rates in a small mountain catchment. Cryosphere 4, 215-225. http://dx.doi.org/10.5194/tc-4-215-2010.

Gubler, S., Fiddes, J., Keller, M., Gruber, S., 2011. Scale-dependent measurement and analysis of ground surface temperature variability in alpine terrain. Cryosphere 5, 431-443. http://dx.doi.org/10.5194/tc-5-431-2011.

Haberkorn, A., Phillips, M., Kenner, R., Rhyner, H., Bavay, M., Galos, S.P., Hoelzle, M., 2015. Thermal regime of rock and its relation to snow cover in steep Alpine rock walls: Gemsstock, central Swiss Alps. Geogr. Ann., Ser. A xx, 1-19. http://dx.doi.org/10. 1111/geoa.12101.

Haeberli, W., Wegmann, M., Vonder Mühll, D., 1997. Slope stability problems related to glacier shrinkage and permafrost degradation in the Alps. Eclogae Geol. Helv. 90, 407-414. http://dx.doi.org/10.5169/seals-168172.

Hasler, A., Gruber, S., Haeberli, W., 2011. Temperature variability and offset in steep alpine rock and ice faces. Cryosphere 5, 977-988. http://dx.doi.org/10.5194/tc-5977-2011.

Hoelzle, M., Haeberli, W., Stocker-Mittaz, C., 2003. Miniature ground temperature data logger measurements 2000-2002 in the Murtèl-Corvatsch area, Eastern Swiss Alps. In: Phillips, M., Springman, S., Arenson, L. (Eds.), Proceedings of the 8th International Conference on Permafrost. Swets \& Zeitlinger, Lisse, pp. 419-424.

Integrated, Maxim, 2013. DS1922L/DS1922T iButton Temperature Loggers with 8 kB Data-log Memory. Maxim Integrated Products, San Jose, p. 52

IPCC (Intergovernmental Panel on Climate Change), 2013. Contribution of Working Group I to the Fifth Assessment Report of the Intergovernmental Panel on Climate Change. Cambridge University Press, Cambridge and New York (1535 p).

Keller, F., Gubler, H., 1993. Interaction between snow cover and high mountain permafrost, Murtèl-Corvatsch, Swiss Alps. In: Guodong, C. (Ed.), Proceedings of the 6th International Conference on Permafrost. South China University, Technology Press, pp. 332-337.

Keller, M., Hungerbühler, G., Knecht, O., Skeikh, S., Beutel, J., Gubler, S., Fiddes, J., Gruber, S., 2010. iAssist: rapid deployment and maintenance of tiny sensing systems. SenSys'10, Proceedings of the 8th ACM Conference on Embedded Networked Sensor Systems, pp. 401-402 http://dx.doi.org/10.1145/1869983.1870043.

Kenner, R., Phillips, M., Danioth, C., Denier, C., Thee, P., Zgraggen, A., 2011. Investigation of rock and ice loss in a recently deglaciated mountain rock wall using terrestrial laser scanning: Gemsstock, Swiss Alps. Cold Reg. Sci. Technol. 67, 157-164. http://dx.doi. org/10.1016/j.coldregions.2011.04.006.

Krautblatter, M., Huggel, C., Deline, P., Hasler, A., 2011. Research perspectives on unstable high-alpine bedrock permafrost: measurement, modelling and process understanding. Permafr. Periglac. Process. 23, 80-88. http://dx.doi.org/10.1002/ ppp.740.

Krautblatter, M., Funk, D., Günzel, F.K., 2013. Why permafrost rocks become unstable: a rock-ice-mechanical model in time and space. Earth Surf. Process. Landf. 38, 876-887. http://dx.doi.org/10.1002/esp.3374.

Lehning, M., Löwe, H., Ryser, M., Raderschall, N., 2008. Inhomogeneous precipitation distribution and snow transport in steep terrain. Water Resour. Res. 44, W07404. http:// dx.doi.org/10.1029/2007wr006545.

Lewkowicz, A.G., 2008. Evaluation of miniature temperature-loggers to monitor snowpack evolution at mountain permafrost sites, northwestern Canada. Permafr. Periglac. Process. 19, 323-331. http://dx.doi.org/10.1002/ppp.625.

Luetschg M. Bartelt, P., Lehning M., Stoeckli, V., Haeberli, W. 2003. Numerical simulation of the interaction processes between snow cover and alpine permafrost. In: Phillips, M., Springman, S., Arenson, L. (Eds.), Proceedings of the 8th International Conference on Permafrost. Sweets \& Zeitlinger, Lisse, pp. 697-702.

Luetschg, M., Lehning, M., Haeberli, W., 2008. A sensitivity study of factors influencing warm/ thin permafrost in the Swiss Alps. J. Glaciol. 54, 696-704. http://dx.doi.org/ 10.3189/002214308786570881.

Magnin, F., Deline, P., Ravanel, L., Noetzli, J., Pogliotti, P., 2015. Thermal characteristics of permafrost in the steep alpine rock walls of the Aiguille du Midi (Mont Blanc Massif, 3842 m a.s.l.). Cryosphere 9, 109-121. http://dx.doi.org/10.5194/tc-9-109-2015.

Matsuoka, N., Sakai, H., 1999. Rockfall activity from an alpine cliff during thawing periods. Geomorphology 28, 309-328. http://dx.doi.org/10.1016/S0169-555X(98)00116-0.

Mittaz, C., Hoelzle, M., Haeberli, W., 2000. First results and interpretation of energy-flux measurements over Alpine permafrost. Ann. Glaciol. 31, 275-280. http://dx.doi.org/ $10.3189 / 172756400781820363$.

Mott, R., Egli, L., Grünewald, T., Dawes, N., Manes, C., Bavay, M., Lehning, M., 2011. Micrometeorological processes driving snow ablation in an Alpine catchment. Cryosphere 5, 1083-1098. http://dx.doi.org/10.5194/tc-5-1083-2011.

Noetzli, J., Gruber, S., Kohl, T., Salzmann, N., Haeberli, W., 2007. Three-dimensional distribution and evolution of permafrost temperatures in idealized high-mountain topography. Geophys. Res. 112, F02S13. http://dx.doi.org/10.1029/2006JF000545.

PERMOS, 2013. Permafrost in Switzerland 2008/2009 and 2009/2010. In: Noetzli, J. (Ed.), Glaciological Report (Permafrost) No. 10/11 of the Cryospheric Commission of the Swiss Academy of Sciences, p. 80.

Phillips, M., Schweizer, J., 2007. Effect of mountain permafrost on snowpack stability. Cold Reg. Sci. Technol. 47, 43-49. http://dx.doi.org/10.1016/j.coldregions.2006.08.010. 
Pomeroy, J.W., Gray, D.M., 1995. Snowcover accumulation, relocation and management. National Hydrology Research Institute Science Report No. 7, Environment Canada, Saskatoon.

Prokop, A., 2008. Assessing the applicability of terrestrial laser scanning for spatial snow depth measurements. Cold Reg. Sci. Technol. 54, 155-163. http://dx.doi.org/10. 1016/j.coldregions.2008.07.002.

Ravanel, L., Deline, P., 2010. Climate influence on rockfalls in high-Alpine steep rock walls: the north side of the Aiguilles de Chamonix (Mont Blanc Massif) since the end of the "Little Ice Age". The Holocene 21, 357-365. http://dx.doi.org/10.1177/ 0959683610374887

Sappington, J., Longshore, K., Thomson, D., 2007. Quantifying landscape ruggedness for animal habitat analysis: a case study using bighorn sheep in the Mojave Desert J. Wildl. Manag. 71, 1419-1426. http://dx.doi.org/10.2193/2005-723.

Schmid, M.O. Gubler, S., Fiddes, J., Gruber, S., 2012. Inferring snowpack ripening and melt-out from distributed measurements of near-surface ground temperatures. Cryosphere 6, 1127-1139. http://dx.doi.org/10.5194/tc-6-1127-2012.

Schmidt, S., Weber, B., Winiger, M., 2009. Analyses of seasonal snow disappearance in an alpine valley from micro- to meso-scale (Loetschental, Switzerland). Hydrol. Process. 23, 1041-1051. http://dx.doi.org/10.1002/hyp.7205.

Schweizer, J., Kronholm, K., Jamieson, J.B., Birkeland, K.W., 2008. Review of spatial variability of snowpack properties and its importance for avalanche formation. Cold Reg. Sci. Technol. 51, 253-272. http://dx.doi.org/10.1016/j.coldregions.2007.04.009.

Seligman, G., 1936. Snow Structure and Ski Fields. International Glaciological Society, Cambridge, UK.
Smith, M.W., Riseborough, D.W., 2002. Climate and the limits of permafrost: a zonal analysis. Permafr. Periglac. Process. 13, 1-15. http://dx.doi.org/10.1002/ppp.410.

Sturm, M., Holmgren, J., König, M., Morris, K., 1997. The thermal conductivity of seasonal snow. J. Glaciol. 43, 26-41.

Trujillo, E., Ramirez, J.A., Elder, K.J., 2007. Topographic, meteorologic, and canopy controls on the scaling characteristics of the spatial distribution of snow depth fields. Water Resour. Res. 43, 1-17. http://dx.doi.org/10.1029/2006WR005317.

Veitinger, J., Sovilla, B., Purves, R.S., 2014. Influence of snow depth distribution on surface roughness in alpine terrain: a multi-scale approach. Cryosphere 8, 547-569. http:// dx.doi.org/10.5194/tc-8-547-2014.

Williams, P.J., Smith, M.W. (Eds.), 1989. The Frozen Earth: Fundamentals of Geocryology. Cambridge University Press, Cambridge (306 pp).

Winstral, A., Elder, K., Davis, R., 2002. Spatial snow modelling of wind-redistributed snow using terrain-based parameters. J. Hydrometeorol. 3, 524-538. http://dx.doi.org/10. 1175/1525-7541(2002)003<0524:SSMOWR $>2.0$. .CO;2.

Wirz, V., Schirmer, M., Gruber, S., Lehning, M., 2011. Spatio-temporal measurements and analysis of snow depth in a rock face. Cryosphere 5, 893-905. http://dx.doi.org/10. 5194/tc-5-893-2011.

Zhang, T., 2005. Influence of the seasonal snow cover on the ground thermal regime: an overview. Rev. Geophys. 43, RG4002. http://dx.doi.org/10.1029/2004RG000157.

Zhang, T., Barry, R.G., Haeberli, W., 2001. Numerical simulations of the influence of the seasonal snow cover on the occurrence of permafrost at high latitudes. Nor. Geogr. Tidsskr. 55, 261-266. http://dx.doi.org/10.1080/00291950152746621. 